Doi: HTTPS://DOI.ORG/10.23910/IJBSM/2017.8.2.1704

\title{
Response of Organic Nutrient Management Practices on Soil Properties and Productivity of Chickpea (Cicer arietinum L.)
}

\author{
S. K. Sharma ${ }^{1}$, Roshan Choudhary ${ }^{2}$, Amit Trivedi ${ }^{3}$, R. S. Choudhary ${ }^{4 *}$ and Shrawan K. Yadav ${ }^{5}$
}

${ }^{1}$ Agriculture Research Station, Directorate of Research, ${ }^{3}$ Deptt. of Pathology, ${ }^{2,4 \& 5}$ Deptt. of Agronomy, Rajasthan College of Agriculture, Maharana Pratap University of Agriculture \& Technology, Udaipur, Rajasthan (313 001), India

\section{Corresponding Author}

R. S. Choudhary

e-mail: agroudr2013@gmail.com

\author{
Article History \\ Manuscript No. AR1704 \\ Received in $30^{\text {th }}$ September, 2016 \\ Received in revised form $17^{\text {th }}$ March, 2017 \\ Accepted in final form $6^{\text {th }}$ April, 2017
}

\begin{abstract}
Field experiment was conducted on sandy clay loam soil at Instructional Farm, Department of Agronomy, Rajasthan College of Agriculture, Udaipur (Rajasthan), India during rabi seasons of 2012-13, 2013-14 and 2014-15 to study the development of nutrient management practices for production of organic chickpea (Cicer arietinum L.). The experiment was laid out in randomized plot design and replicated thrice with ten treatments. Application of organic manures resulted in significantly higher organic carbon, available nitrogen, phosphorus and potassium as compared to other treatment over three years. The soil applied organic manures and foliar spray of biodynamic manures significantly enhanced the growth and yield parameters of chickpea viz., plant height, number of branches, and number of pods plant ${ }^{-1}$, 100 -seed weight, grain yield and haulm yield. Application of vermicompost $2 \mathrm{t} \mathrm{ha}^{-1}$ as basal+vermicompost $2 \mathrm{t}$ ha ${ }^{-1}$ at $40 \mathrm{DAS}+\mathrm{mustard}$ cake $1 \mathrm{t} \mathrm{ha}^{-1}$ as basal+Rhizobium+PSB+BD-500 $75 \mathrm{~g} \mathrm{ha}^{-1}$ before sowing and 30 DAS+BD-501 $2.5 \mathrm{~g} \mathrm{ha}^{-1}$ at 2-4 leaf and pre-flowering stage recorded significantly higher seed yield $\left(1748 \mathrm{~kg} \mathrm{ha}^{-1}\right)$, haulm yield $\left(5416 \mathrm{~kg} \mathrm{ha}^{-1}\right)$, number of pods plant ${ }^{-1}(114.92)$ and number of grains pod ${ }^{-1}(1.48)$ compared to other treatments. Similarly, maximum net return ( $₹ 40631 \mathrm{ha}^{-1}$ ) was also recorded with application of vermicompost $2 \mathrm{t}$ ha $\mathrm{a}^{-1}$ as basal+vermicompost $2 \mathrm{t} \mathrm{ha}^{-1}$ at $40 \mathrm{DAS}+$ mustard cake $1 \mathrm{t} \mathrm{ha}^{-1}+$ Rhizobium+PSB+BD-500+BD-501 which recorded an increase of 76.08\% and $26.49 \%$ higher over control and application of FYM $8 \mathrm{t} \mathrm{ha}^{-1}+$ Rhizobium+PSB, respectively.
\end{abstract}

Keywords: Biodynamic, chickpea, mustard cake, Rhizobium, vermicompost

\section{Introduction}

Chickpea (Cicer arietinum L.) is the third most widely grown grain legume in the world after bean and soybean. It produces $126 \mathrm{~kg}$ protein from one hectare and is probably the highest protein yielding grain legume except, groundnut and soybean. A $100 \mathrm{~g}$ of chickpea seeds provide 360 calories more energy than any other legume except ground nut and lucerne. Chickpea remarkably predominate among other pulse crops in terms of both area and production. In India, it is cultivated on an area of 10.2 mha with a production of $9.9 \mathrm{mt}$ and productivity of $967 \mathrm{~kg} \mathrm{ha}^{-1}$ (Economic Survey, 2015). Rajasthan state occupies 1.92 mha under chickpea with production of $1.64 \mathrm{mt}$ and productivity of $853 \mathrm{~kg} \mathrm{ha}^{-1}$ (Agricultural Statistics, 2015). It is often hard to quantify the effect of organic management practices on nutrient cycles because of the fact that organic agriculture is not about substitution of input for input, but the overall development of soil health. Application of organic manure builds up soil health and sustains crop production for longer time. However, single organic source of nutrient supplementation may not cope up with the nutrient demand of crops. Integration of different organic nutrient sources and/or liquid organic manures help to solve dual problem of supplementation of sufficient nutrients besides synchronized nutrient availability as per crop demand associated with variable nutrient release pattern among different organic manures In the present study, scientific validation of effect of vermicompost, BD-500 and BD-501, Rhizobium, PSB and mustard cake have been investigated on soil properties, productivity \& economics of organic chickpea.

It is often hard to quantify the effect of organic management practices on nutrient cycles because of the fact that organic agriculture is not about substitution of input for input, but the overall development of soil health. However, single organic source of nutrient supplementation may not cope up with the nutrient demand of crops. Integration of different organic nutrient sources help to solve dual problem of supplementation of sufficient nutrients besides synchronized nutrient availability as per crop demand associated with variable nutrient release pattern among different organic manures. 


\section{Materials and Methods}

Chickpea (Cicer arietinum L.) was grown under organic management practices at Instructional Farm, Rajasthan College of Agriculture, Udaipur (Rajasthan), India during rabi seasons of 2012-13, 2013-14 and 2014-15.The soil of the experimental site was sandy clay loam in texture with bulk density of $1.42 \mathrm{~g} \mathrm{cc}^{-1}, \mathrm{pH}$ of 7.90 , organic carbon of $0.42 \%$. Initially, the soil was containing available $\mathrm{N}$ as $223.42 \mathrm{~kg} \mathrm{ha}^{-1}$, $\mathrm{P}_{2} \mathrm{O}_{5}$ as $30.96 \mathrm{~kg} \mathrm{ha}^{-1}$ and available $\mathrm{K}_{2} \mathrm{O}$ as $262.25 \mathrm{~kg} \mathrm{ha}^{-1}$. The experiment was laid out in randomized block design with three replications. There were 10 treatments consisting of $\mathrm{T}_{1}$ : FYM $8 \mathrm{t} \mathrm{ha}^{-1}+$ Rhizobium+PSB, $\mathrm{T}_{2}$ : FYM $4 \mathrm{t} \mathrm{ha}^{-1}+$ Mustard cake $1 \mathrm{t} \mathrm{ha}^{-1}+$ Rhizobium+PSB, $\mathrm{T}_{3}$ : FYM $8 \mathrm{t} \mathrm{ha}^{-1}+\mathrm{BD}-500+\mathrm{BD}-$ 501+Rhizobium+PSB, T: FYM $4 \mathrm{t} \mathrm{ha}^{-1}+$ Mustard cake $1 \mathrm{t} \mathrm{ha-1}$ + Rhizobium+PSB+BD-500+BD-501, $\mathrm{T}_{5}$ : Vermicompost $4 \mathrm{tha}^{-1}$ + Rhizobium+PSB, $\mathrm{T}_{6}$ : Vermicompost $2 \mathrm{t} \mathrm{ha}^{-1}+$ Mustard cake $1 \mathrm{t}$ ha $^{-1}+$ Rhizobium+PSB, $\mathrm{T}_{7}$ : Vermicompost 4 t ha ${ }^{-1}+\mathrm{BD}-500+\mathrm{BD}-$ $501+$ Rhizobium+PSB, $\mathrm{T}_{8}$ : Vermicompost $2 \mathrm{t} \mathrm{ha}^{-1}+$ Mustard cake 1 t ha ${ }^{-1}+$ Rhizobium+PSB+BD-500+BD-501, $\mathrm{T}_{9}$ : Vermicompost $2 \mathrm{t} \mathrm{ha}^{-1}$ as basal+Vermicompost $2 \mathrm{t} \mathrm{ha}^{-1}$ at 40 DAS+Mustard cake $1 \mathrm{t} \mathrm{ha}^{-1}+$ Rhizobium+PSB+BD-500+BD-501 and $\mathrm{T}_{10}$ : control. The recommended dose of nitrogen \& phosphorus for chickpea was 20 and $40 \mathrm{~kg} \mathrm{ha}^{-1}$. Organic manures were applied by considering equivalency of recommended dose of phosphorus. Seed were treated with Rhizobium and

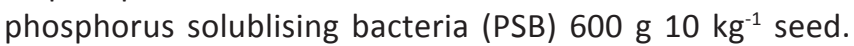
The chickpea variety GNG-469 was sown with a spacingof $30 \times 10 \mathrm{~cm}^{2}$. Soil application of neem cake was applied before sowing at $2 \mathrm{q} \mathrm{ha}^{-1}$ (for soil borne insects)+Trichoderma $2 \mathrm{~kg}$ ha $^{-1}$ incubatedfor 15 days on 100 kg FYM. FYM, vermicompost and mustard cake (as treatments ${ }^{-1}$ ) were applied in all the treatment plots except control. The recommended dose of nitrogen forchickpea was supplemented with different combinations of organic manures with equal proportions based on their nitrogencontent. All other agronomic practices were kept uniform for all the treatments. Pest \& diseases in the crop were managed by organic methods recommended under National Programme of Organic Production (India). Growth and yield attributes and yield were recorded by adopting the standard procedures and nutrient content and uptake were analysed and calculated by standard formulae and methods along with calculation of economic returns.

Method of preparation of biodynamic manure (BD-500 and BD-501): The cow horn manure (BD-500) was prepared at the Organic Farming Unit of RCA Farm, Udaipur. BD-500 has been prepared by stuffing the dung of a lactating cow into a horn and buried in the soil during the autumn equinox (September) and taken out during the spring equinox (March). The humified dung from horn is stored in an earthen pot away from sunlight. For preparing the spray solution for one ha, $62.5 \mathrm{~g}$ of this material was dissolved in $40 \mathrm{I}$ of warm water $\left(40{ }^{\circ} \mathrm{C}\right.$ ) with continuous stirring for $1 \mathrm{hr}$ (alternately in clock wise and anti-clock wise directions). The liquid mixture was sprinkled as big droplets on soil surface in the evening on day before sowing. Based on biodynamic calendar, BD-500 was applied during the lunar descending period, when the effects are supposedly better (Brinton, 1998). On the other hand biodynamic formulations (BD-501) sourced from the SUPA Biotech (P) Ltd., Nainital, India were tried. BD-501 is "cow horn silica" and is made from quartz crystals ground to alum power consistency, stuffed into a cow horn, buried during spring equinox, and taken out during autumn equinox. The material, stored in glass bottle, and exposed to the sun by the windows. It was used to prepare the BD-501 spray solution by dissolving $2.5 \mathrm{~g}$ in $40 \mathrm{l}$ of water at at 2-4 leaf stage and at pre-flowering stage, which was prepared for spray within an hour, the mixture was sprayed as a fine mist on the plant foliage (i.e. before $9.00 \mathrm{am}$ ). The application dates corresponded to days when moon was opposite to Saturn in the biodynamic calendar.

\section{Results and Discussion}

Results of the pooled data of three years i.e., 2012-13, 2013-14 and 2014-15 revealed a significant effect of organic management practices on soil properties. Maximum organic carbon (0.62\%), nitrogen (354 kg ha ${ }^{-1}$ ), phosphorus (49.3 $\mathrm{kg} \mathrm{ha}^{-1}$ ) and potassium (285 $\mathrm{kg} \mathrm{ha}^{-1}$ ) were observed with vermicompost $2 \mathrm{t}$ ha-1+Mustard cake $1 \mathrm{t} \mathrm{ha}{ }^{-1}+$ Rhizobium+ PSB+BD-500+BD-501 and was found significantly superior over other treatments. The organic carbon of soil was significantly affected by nutrient management practices at the end of third year (Table 1) as compared to initial values. This can be ascribed to continuous use of organic manures. Organic carbon contents of soil changes rapidly with addition of organic manures. Sharma and Subehia (2003) also reported greater levels of soil organic carbon under organic production system. Legume crop like chickpea add handsome crop biomass in soil and also helped in increasing the available phosphorus in the soil by mineralization or solubilising the native phosphorus reserves.

Further, the liquid organic manures meet the nutrient requirement of crops with greater nutrient use efficiency and also correct the deficiency of nutrients as and when noticed under organic production system (Shwetha, 2009).

Data also revealed a significant effect of organic methods of nutrient management on yield attributes and yield of chickpea. The application of vermicompost $2 \mathrm{t} \mathrm{ha-1}$ as basal+vermicompost $2 \mathrm{t} \mathrm{ha}^{-1}$ at 40 DAS+mustard cake $1 \mathrm{t}$ ha $^{-1}+$ Rhizobium+PSB+BD-500+BD-501 recorded significantly higher plant height, number of pods plant ${ }^{-1}$ (114.92) and number of grains pod $^{-1}(1.48)$ as compared to all other treatments (Table 2 and Figure 1) and the same treatment was also recorded significantly higher seed yield (1748 kg ha-1), haulm yield (5416 kg ha-1), seed index (21.12) and biological yield (7164 $\mathrm{kg} \mathrm{ha}^{-1}$ ) compare to other combination of sources of nutrient (Table 2 and Figure 2), which might 
be due to the improvement in soil physical condition for the plant growth along with increased availability of micro and macro nutrients at the early stage of crop growth. BD-500 and BD-501 also called as bio-enhancers are rich source of microbial consortia, macro and micronutrients and plant growth promoting substances including immunity

Table 1: Effect of different organic nutrient management practices on available nutrients in soil (after three year of study on chickpea on pooled basis)

\begin{tabular}{lcccc}
\hline Treatments & \multicolumn{4}{c}{ Available nutrients } \\
\cline { 2 - 5 } & OC & $\begin{array}{c}\text { Nitrogen } \\
\left(\mathrm{kg} \mathrm{ha}^{-1}\right)\end{array}$ & $\begin{array}{c}\text { Phosphorus } \\
\left(\mathrm{kg} \mathrm{ha}^{-1}\right)\end{array}$ & $\begin{array}{c}\text { Potassium } \\
\left(\mathrm{kg} \mathrm{ha}^{-1}\right)\end{array}$ \\
\hline $\mathrm{T}_{1}$ & 0.50 & 315 & 40.4 & 277 \\
$\mathrm{~T}_{2}$ & 0.56 & 321 & 42.3 & 279 \\
$\mathrm{~T}_{3}$ & 0.53 & 330 & 45.1 & 280 \\
$\mathrm{~T}_{4}$ & 0.57 & 270 & 36.0 & 273 \\
$\mathrm{~T}_{5}$ & 0.51 & 266 & 35.1 & 272 \\
$\mathrm{~T}_{6}$ & 0.52 & 250 & 33.2 & 270 \\
$\mathrm{~T}_{7}$ & 0.60 & 310 & 38.1 & 275 \\
$\mathrm{~T}_{8}$ & 0.62 & 354 & 49.3 & 285 \\
$\mathrm{~T}_{9}$ & 0.55 & 350 & 47.2 & 282 \\
$\mathrm{~T}_{10}$ & 0.45 & 236 & 31.4 & 263 \\
$\mathrm{SEm}+$ & 0.01 & 4.30 & 0.62 & 2.15 \\
$\mathrm{CD}(p=0.05)$ & 0.02 & 12.79 & 1.86 & 6.39 \\
Initial value & 0.42 & 223.42 & 30.96 & 262.25 \\
\hline
\end{tabular}

OC: Organic carbon (\%) enhancers. Similarly higher seed yield of mungbean were

Plant height $(\mathrm{cm}) \square$ Dry matter $\left(\mathrm{g} \mathrm{plant}^{-1}\right)$ at harvest $\square$ No. of pods plant ${ }^{-1} \rightarrow$ No. of branches $\rightarrow-$ Seed index
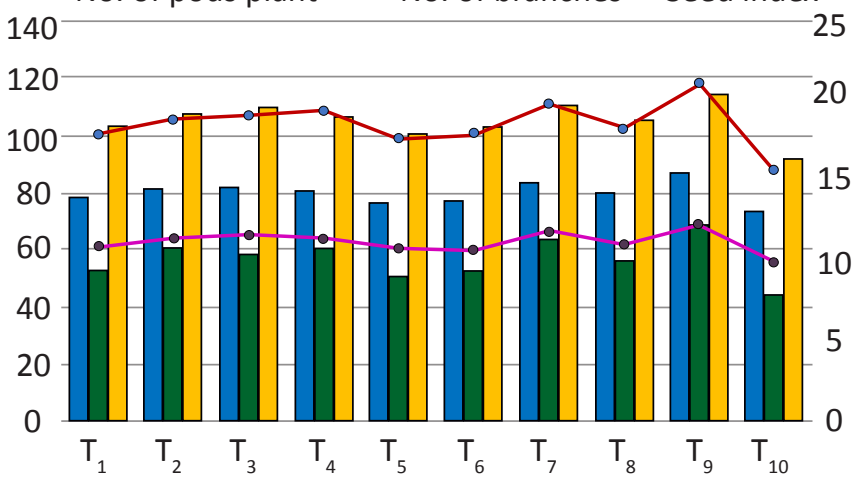

Figure 1: Effect of different nutrient management practices on yield attributes of organic chickpea (Pooled data of three years)

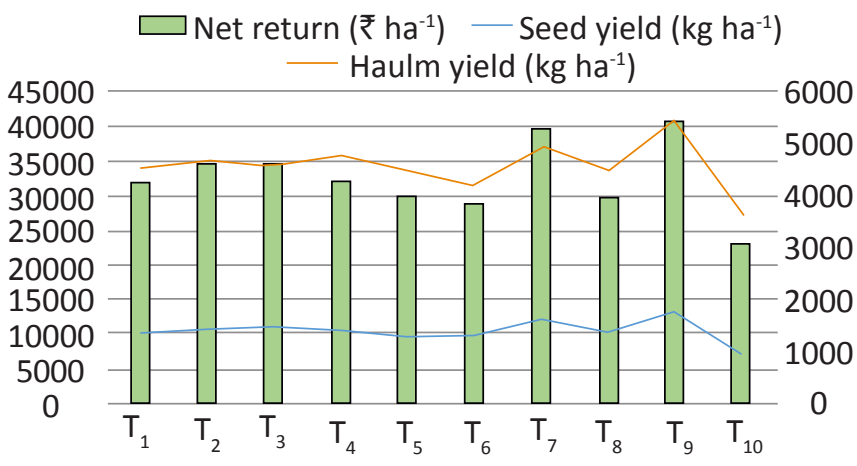

Figure 2: Effect of different nutrient management practices on yield and economics of organic chickpea (Pooled data of three years)

Table 2: Effect of different organic nutrient management practices on growth parameters, yield attributes and yield of chickpea (after three year of study on pooled basis)

\begin{tabular}{lccccccccc}
\hline Treatments & PH & DM & NB & $\begin{array}{c}\text { No. of pods } \\
\text { plant }^{-1}\end{array}$ & $\begin{array}{c}\text { No. of } \\
\text { seeds pod }\end{array}$ & $\begin{array}{c}\text { Seed } \\
\text { index }\end{array}$ & $\begin{array}{c}\text { Seed yield } \\
\left(\text { (k ha }^{-1}\right)\end{array}$ & $\begin{array}{c}\text { Haulm } \\
\text { yield }\left(\mathrm{kg} \mathrm{ha}^{-1}\right)\end{array}$ & $\begin{array}{c}\text { Net return } \\
\left(₹ \text { ha }^{-1}\right)\end{array}$ \\
\hline $\mathrm{T}_{1}$ & 78.83 & 53.11 & 10.96 & 104.13 & 1.24 & 17.99 & 1353 & 4515 & 32121 \\
$\mathrm{~T}_{2}$ & 81.72 & 60.99 & 11.46 & 107.77 & 1.34 & 18.92 & 1481 & 4677 & 34790 \\
$\mathrm{~T}_{3}$ & 82.20 & 58.91 & 11.70 & 110.70 & 1.33 & 19.16 & 1463 & 4572 & 34741 \\
$\mathrm{~T}_{4}$ & 80.94 & 60.49 & 11.48 & 107.02 & 1.36 & 19.47 & 1449 & 4785 & 32098 \\
$\mathrm{~T}_{5}$ & 76.67 & 51.18 & 10.88 & 101.09 & 1.21 & 17.72 & 1281 & 4460 & 29807 \\
$\mathrm{~T}_{6}$ & 77.69 & 52.75 & 10.77 & 103.29 & 1.25 & 18.02 & 1354 & 4161 & 28682 \\
$\mathrm{~T}_{7}$ & 84.14 & 64.11 & 11.89 & 110.83 & 1.41 & 19.84 & 1560 & 4898 & 40032 \\
$\mathrm{~T}_{8}$ & 80.01 & 56.58 & 11.07 & 105.56 & 1.29 & 18.33 & 1410 & 4470 & 29960 \\
$\mathrm{~T}_{9}$ & 87.55 & 69.44 & 12.31 & 114.92 & 1.48 & 21.12 & 1748 & 5416 & 40631 \\
$\mathrm{~T}_{10}$ & 73.89 & 44.69 & 10.00 & 92.22 & 1.08 & 15.75 & 906 & 3593 & 23075 \\
$\mathrm{SEm+}$ & 0.66 & 0.89 & 0.15 & 1.18 & 0.02 & 0.17 & 22 & 84 & 2538 \\
$\mathrm{CD}(p=0.05)$ & 1.95 & 2.65 & 0.46 & 3.51 & 0.06 & 0.52 & 64 & 251 & 32121 \\
\hline
\end{tabular}

PH: Plant height (cm); DM: Dry matter (g plant ${ }^{-1}$ ) at harvest; NB: No. of branches (at harvest) 
also obtained with application of $E C(1 / 3)+V C(1 / 3)+G L M$ (1/3) equivalent $50 \mathrm{~kg} \mathrm{P}_{2} \mathrm{O}_{5}$ with $5 \mathrm{t} \mathrm{FYM} \mathrm{ha-1}\left(1368 \mathrm{~kg} \mathrm{ha}^{-1}\right)$ as compared to (1/3)+VC (1/3)+GLM (1/3) equivalent $50 \mathrm{~kg} \mathrm{P} \mathrm{O}_{5}$ alone $\left(1258 \mathrm{~kg} \mathrm{ha}^{-1}\right)$ and was on par with RDF+FYM (1301 kg $\mathrm{ha}^{-1}$ ) by Yadav et al. (2016). Soil application of $\mathrm{N}$ equivalent to $100 \%$ recommended dose with vermicompost, mustard cake, BD-500 and foliar spray of BD-501 at 2-4 leaf and preflowering stage improved the growth and yield attributing characters of chickpea. It enhanced the growth rate of plant since it contains the favourable micro and macronutrients and growth hormones. The favourable effect of biodynamic manures (BD-500 \& BD-501) on growth and productivity of cumin was also reported by Sharma etal. (2012). Parthasarathi et al. (2008) reported that vermicompost helps in enhancing
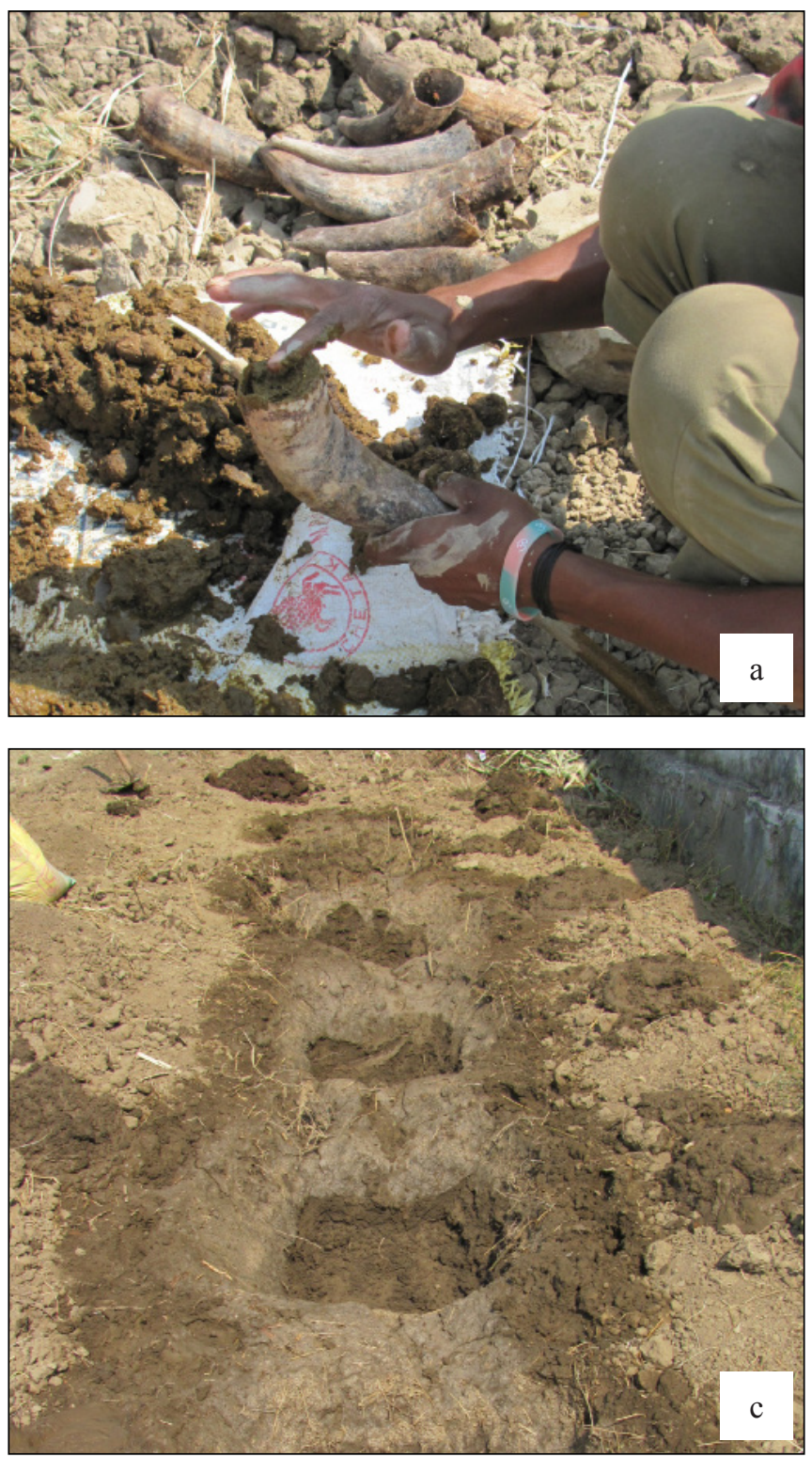

activity of micro-organisms in soils which further enhances solubility of nutrients and their consequent availability to plants. This will help in accomplishing the nutrient demand of chickpea through various organic nutrient sources and reduce the dependence in chemical fertilizers.

Simultaneously, application of vermicompost $2 \mathrm{t} \mathrm{ha}^{-1}$ as basal+vermicompost $2 \mathrm{t} \mathrm{ha}^{-1}$ at $40 \mathrm{DAS}+$ mustard cake $1 \mathrm{t}$ ha ${ }^{1}+$ Rhizobium+PSB+BD-500+BD-501 gave maximum net return of ₹ $40631 \mathrm{ha}^{-1}$ and recorded an increase of $76.08 \%$ and $26.49 \%$ over control and application of FYM $8 \mathrm{t} \mathrm{ha}^{-1}+$ Rhizobium+PSB. Further, split application of vermicompost $2 \mathrm{t} \mathrm{ha}^{-1}$ at 40 DAS along with two spray of BD-500 and BD-501 gave an additional net return of ₹ $10671 \mathrm{ha}^{-1}$ over vermicompost $4 \mathrm{t}$ ha ${ }^{-1}+$ Rhizobium+PSB (Table 2 and Figure 3 ).
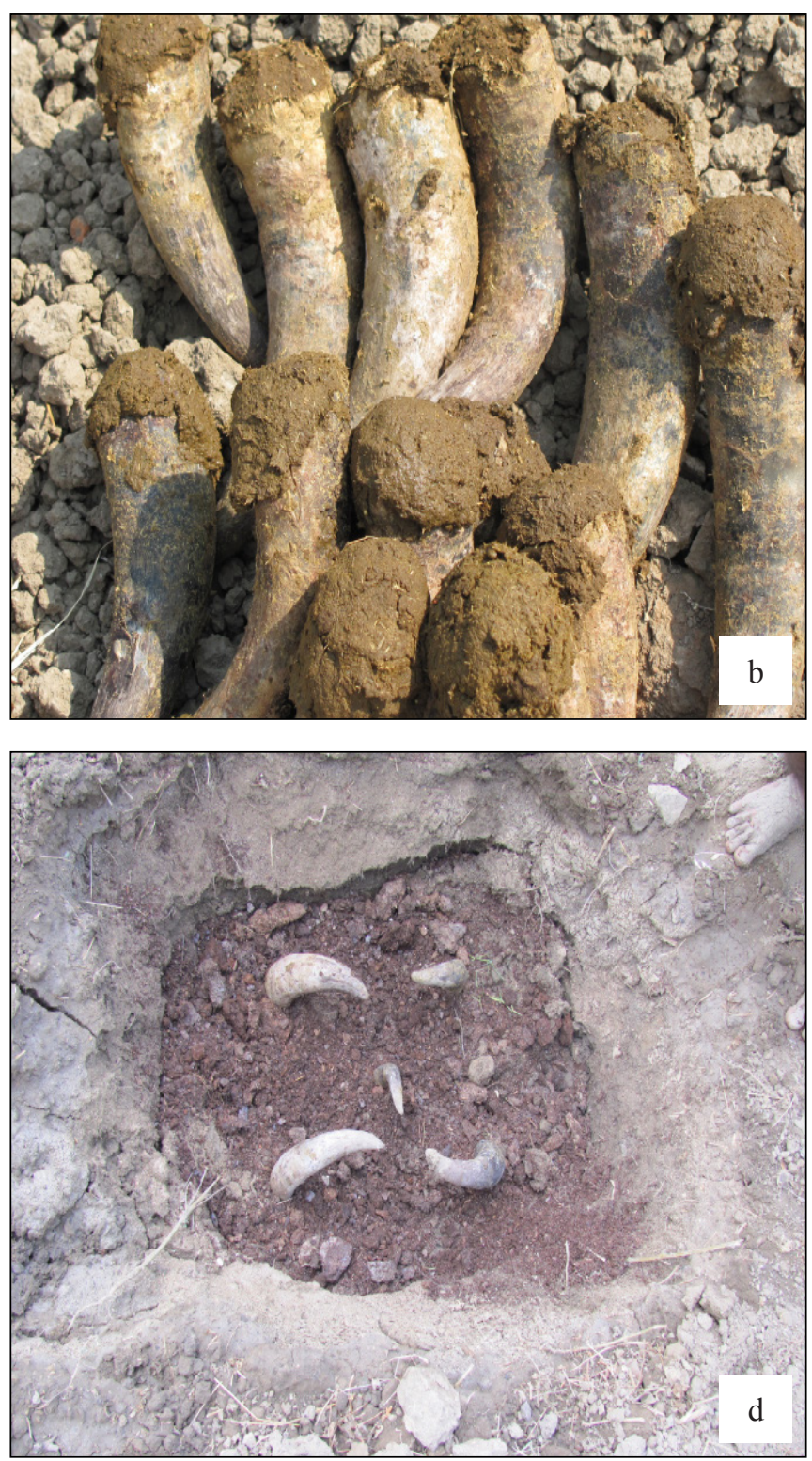

Figure: 3a: Fill cow horn with cow dung BD 500; 3b: Filled cow horn BD 500; 3c: Pit for BD 500; 3d: Putting of filled cow horn in pit BD 500 


\section{Conclusion}

Maximum organic carbon (0.62\%), nitrogen (354 kg ha-1), phosphorus (49.3 $\mathrm{kg} \mathrm{ha}^{-1}$ ) and potassium (285 kg ha-1) were observed with vermicompost $2 \mathrm{t} \mathrm{ha}^{-1}+$ Mustard cake $1 \mathrm{t} \mathrm{ha}^{-1}+$ Rhizobium+PSB+BD-500+BD-501 whereas, significantly higher plant height $(87.55 \mathrm{~cm})$, dry matter g plant ${ }^{-1}(69.44)$, number of branches plant ${ }^{-1}(12.31)$, number of pods plant ${ }^{-1}$ (114.92), number of seeds pod $^{-1}(1.48)$, seed yield $\left(1748 \mathrm{~kg} \mathrm{ha}^{-1}\right)$, haulm yield (5416 kg ha-1), seed index (21.12) and net economic return ( $₹ 40631$ ) were recorded with vermicompost $2 \mathrm{t} \mathrm{ha}^{-1}$ as basal+vermicompost $2 \mathrm{t} \mathrm{ha}^{-1}$ at 40 DAS+mustard cake 1 t ha-1 ${ }^{-1}$ Rhizobium+PSB+BD-500+BD-501 as compared to all other treatments.

\section{References}

Agricultural Statistics, 2015. Department of Agriculture, Government of Rajasthan, 36.

Brinton, W.F., 1998. Dynamic chemical processes underlying BD horn manure (BD-500) preparation. Journal of Biodynamics 214, 1-8.

Economic Survey, 2015. Department of Agriculture, Government of India, 23.

Parthasarathi, K., Balamurugan, M., Ranganathan, L.S., 2008.
Influence of vermicompost on the physico-chemical and biological properties in different types of soil along with yield and quality of the pulse crop-blackgram. Iranian Journal of Environmental Health, Science and Engineering 5(1), 51-58.

Sharma, S.K., Laddha, K.C., Sharma, R.K., Gupta, P.K., Chatta, L.K., Pareek, P., 2012. Application of biodynamic preparations and organic manures for organic production of cumin (Cuminum cyminum L.). International Journal of Seed Spices 2(1), 7-11.

Sharma, S.P., Subehia, S.K., 2003. Effects of twenty-five years of fertilizer use on maize and wheat yields and quality of an acidic soil in the western Himalayas. Experimental Agriculture 39, 55-63.

Shwetha, B.N., Babalad, H.B., Patil, R.K., 2009. Effect of combined use of organics in soybean-wheat cropping system. Journal of Soil and Crops 19(1), 8-13.

Kumar, S.Y., Babalad, H.B., Sharma, S.K., Choudhary, R.S., Kumar, N., 2016. Impact of Organic Nutrient Management Practices on Yield Attributes and Yield of Summer Mungbean. International Journal of Bioresource and Stress Management. 7(5), 1136-1139. 